\title{
EGFR inhibition in non-small cell lung cancer: current evidence and future directions
}

Alexander Chi ${ }^{*}$, Scot Remick ${ }^{2}$ and William Tse ${ }^{3}$

\begin{abstract}
EGFR inhibition has emerged to be an important strategy in the treatment of non-small cell lung cancer (NSCLC). Small molecule tyrosine kinase inhibitors (TKIs) and mono-clonal antibodies (mAbs) to the EGFR have been tested in multiple large randomized phase III studies alone or combined with chemotherapy, as well as small phase I-II studies which investigated their efficacy as radiosensitizers when combined with radiotherapy. In this review, we described the current clinical outcome after treatment with EGFR TKIs and mAbs alone or combined with chemotherapy in advanced stage NSCLC, as well as the early findings in feasibility/phase I or II studies regarding to whether EGFR TKI or mAb can be safely and effectively combined with radiotherapy in the treatment of locally advanced NSCLC. Furthermore, we explore the potential predictive biomarkers for response to EGFR TKls or mAbs in NSCLC patients based on the findings in the current clinical trials; the mechanisms of resistance to EGFR inhibition; and the strategies of augmenting the antitumor activity of the EGFR inhibitors alone or when combined with chemotherapy or radiotherapy.
\end{abstract}

Keywords: EGFR, NSCLC, EGFR mutations, Radiotherapy, Resistance

\section{Introduction}

The epidermal growth factor receptor (EGFR), a $170 \mathrm{kD}$ transmembrane protein consisted of a N-terminus extracellular ligand-binding site, a hydrophobic transmembrane domain, and a C-terminus intracellular region with tyrosine kinase activity, is the first of the ErbB family of receptor tyrosine kinases (RTKs) [1,2]. The other members include ErbB2 (HER2/neu), ErbB3 (HER3), and ErbB4 (HER4). These receptors trigger downstream signaling pathways which lead to multilayered, complex interactions resulting in combinatorial responses. Disruption of these pathways was found to cause malignant transformation [1]. The EGFR is activated through ligand-induced homo or heterodimerization of the receptor with other receptors of the ErbB family under physiologic conditions, but can also be activated due to receptor over-expression, increase of EGFR gene copy number, and activating mutations [3]. EGFR activation has been shown to play a key role in tumor cell proliferation, apoptosis, tumor-induced angiogenesis, metastasis, and DNA damage repair after

\footnotetext{
* Correspondence: achiaz2010@gmail.com

'Department of Radiation Oncology, West Virginia University, Morgantown, WW 26506, USA

Full list of author information is available at the end of the article
}

cytotoxic insults $[1,4]$. This makes it an attractive target in cancer therapy; and its inhibition a strategy for augmentation of the efficacy of chemotherapy and radiotherapy. Since the initial discovery of the EGFR in 1962, a class of antibodies blocking the EGFR's extra-cellular ligand binding site to prevent receptor activation, and to downregulate EGFR expression at the cell surface through antibody mediated receptor dimerization; and low molecular weight tyrosine kinase inhibitors, which competes with ATP to bind to the intra-cellular tyrosine kinase portion of the receptor to abrogate the receptor's catalytic activity to activate downstream signaling pathways, have been developed [1,4-6]. Among them, reversible small molecule (SM) tyrosine kinase inhibitors (TKIs), Gefitinib and Erlotinib, and the mono-clonal antibody (mAb) against EGFR, Cetuximab, have been the most thoroughly investigated. Both Cetuximab and the SM TKIs have been shown to have significant antitumor activity in various EGFR overexpressing cancers, and to enhance the potency of chemotherapy or radiotherapy in various pre-clinical and early phase I or II clinical studies [1,6-8].

As the leading cause of cancer mortality worldwide, $50-80 \%$ of non-small cell lung cancer (NSCLC) is associated with EGFR overexpression; with $65 \%$ of them also 
found to have an increased EGFR gene copy number [9-11]. Given the high percentage of NSCLC being diagnosed in the advanced stage with a poor survival outcome, EGFR inhibition alone or combined with other approaches in the treatment of NSCLC become a very attractive strategy which has been validated in preclinical and preliminary clinical trials [12-14]. This led to further phase III randomized studies assessing the efficacy of combining a SM TKI or Cetuximab with chemotherapy as the first line treatment of stage IIIB-IV NSCLC; and some feasibility/phase I \& II studies on their combination with radiotherapy, or chemo-radiation in the treatment of local-regional disease. In the following sections, we will describe the current clinical evidence on the utility of TKIs and Cetuximab with chemotherapy in the treatment of advanced stage NSCLC, their role in the treatment of loco-regionally confined NSCLC, such as radiosensitization; patient selection, and potential strategies of further enhancing their efficacy.

\section{EGFR TKIs alone or combined with chemotherapy as first line treatment}

Numerous phase III studies on TKI alone or combined with chemotherapy as first line treatment for stage IIIBIV NSCLC have been conducted since Gefitinib has been approved by the Food and Drug Administration (FDA) in 2003, and Erlotinib has been approved by the FDA in 2004 for chemotherapy-resistant stage IIIB-IV NSCLC [14-23]. In 2004, two large phase 3 randomized studies evaluating the benefit of adding Gefinitib to chemotherapy as first line treatment for stage IIIB-IV NSCLC have been reported [15,16]. In INTACT 1, 1093 patients were randomized to placebo, Gefitinib $250 \mathrm{mg} /$ day, and Gefitinib $500 \mathrm{mg} /$ day after up to six cycles of Cisplatin and Gemcitabine. No differences in objective response rate (ORR), progression free survival (PFS), or overall survival (OS) was found between the 3 arms after median follow up of 15.9 months. The treatment was very well tolerated with no difference in the incidence of interstitial lung disease (ILD) reported and an overall incidence of ILD $<1 \%$ [15]. In a parallel study, INTACT 2 , similar findings were obtained after randomizing 1037 patients to placebo, Gefitinib $250 \mathrm{mg} /$ day, and Gefitinib $500 \mathrm{mg} /$ day after up to 6 cycles of Carboplatin and Paclitaxel in as first line treatment for stage IIIB/IV patients [16]. The addition of Gefitinib was again very well tolerated with only $0.9 \%, 2.1 \%$, and $1.5 \%$ of ILD found in the three arms, respectively. In the subsequent year, a randomized trial (TRIBUTE) comparing first line Carboplatin and Paclitaxel up to 6 cycles and the same regimen combined with concurrent and maintenance Erlotinib (150 mg/day) in 1079 patients [17]. In this study, no difference in ORR, PFS, or OS was found between the two arms. However, a survival benefit from maintenance Erlotinib was found in patients who lived longer than 4 months, which suggested a benefit from maintenance therapy with Erlotinib. There were 5 cases of ILD-like in the Erlotinib arm (1.0\%) and 1 on the chemotherapy arm (0.2\%). All cases were fatal. Despite the overall negative findings in this study, never smokers, who tend to be younger, female, and have adenocarcinomas when compared with prior/current smokers, were found to have a median survival of 22.5 months with Erlotinib treatment and only 10.1 months when treated with placebo.

Despite the disappointment with the INTACT and TRIBUT studies, the importance of selecting patients who will respond to TKIs has been recognized, which is suggested by the prolonged survival observed in never smokers [16,17]. This concept is also supported by the findings of in-frame deletions in exon 19 and missense mutations in exon 21 of the EGFR gene which lead to increased signaling through the EGFR pathway, and increased drug affinity at the EGFR's intra-cellular tyrosine kinase ATP-binding site $[24,25]$. Furthermore, the above mentioned EGFR mutations are more often found in never-smokers as well [17].

To further classify the patients who will respond to EGFR TKIs, a phase III randomized study (IPASS) comparing upfront Geftinib and Carboplatin/Paclitaxel in stage IIIB-IV patients with the following characteristics has been conducted in East Asia: never or former light smokers with a diagnosis of adenocarcinoma [18]. A total of 1217 patients were randomized in this study. After a median follow up of 5.6 months, a superior 1 year PFS with Gefitinib was found $(24.9 \% v s .6 .7 \%, p<0.001)$. Better ORR associated with Gefitinib was also reported (43\% vs. 32.2\%, $p$ <0.001). Among 437 patients whose EGFR mutation data can be evaluated, 261 had EGFR mutations identified. Out of these 261 patients, 53.6\% had exon 19 deletions, and $42.5 \%$ had a missense mutation at exon 21. A predictor of TKI resistance [26,27], a mutation at exon 20 (T790M) was also identified in $4.2 \%$ of these patients. Among patients who harbored activating EGFR mutations on exon 19 and 21, a noticeably increased ORR in patients who received Gefitinib was found when compared with those who received chemotherapy $(71.2 \%$ vs. $47.3 \%, p<0.001)$. The opposite was found in patients without EGFR mutations $(1.1 \% v s$. $23.5 \%, p<0.001)$. No significant difference in toxicity profile between the two treatment arms was found. This study established that EGFR mutation, such as those on exon 19 and 21, can be used as a predictive marker for response to EGFR TKIs, which may be more effective than chemotherapy in patients with these mutations. Its findings were further validated in several other phase 3 randomized studies [19-22]. All these studies included 
patients with sensitive EGFR mutations in exons 19 and 21 only. All four studies confirmed the superior response and PFS associated with an EGFR TKI over chemotherapy in patients with activating EGFR mutations. The details of these studies along with the studies described above are shown in Table 1. One more recent report of a trial (TORCH) comparing first line Erlotinib and Cisplatin/Gemcitabine (CG) followed by either CG or Erlotinib in unselected patients with stage IIIB-IV patients has demonstrated negative outcomes associated with Erlotinib after a median follow up of 24.3 months [23]. Thus, further validating the need to select patients based on specific EGFR mutations in NSCLC patients that are associated with drug sensitivity to EGFR TKIs.

\section{EGFR TKIs as $\mathbf{2}^{\text {nd }}$ line or maintenance therapy}

While effective only in EGFR mutation positive patients as first line treatment, both Gefitinib and Erlotinib have been shown to achieve similar ORR, PFS, and OS when compared with $2^{\text {nd }}$ line chemotherapy in randomized phase 3 studies [28,29]. EGFR FISH-negative tumors were found to have a higher risk of disease progression after Erlotinib in one study [29]. When compared with placebo as maintenance therapy, Erlotinib treatment led

Table 1 Phase III studies investigating the efficacy of EGFR inhibition alone or as part of the $1^{\text {st }}$ line treatment for stage IIIB-IV NSCLC

\begin{tabular}{|c|c|c|c|c|c|c|}
\hline Study & Stage & Study arms & \# Pts & ORR & Median PFS & Median OS \\
\hline \multicolumn{7}{|l|}{$T K I$} \\
\hline INTACT 1 [15] & IIIB-IV & $\begin{array}{l}\text { Cisplatin + Gemcitabine } \\
\text { (CG) vs. CG + Gefitinib } \\
250 \text { mg/d vs. CG + } \\
\text { Gefitinib } 500 \text { mg/d }\end{array}$ & $\begin{array}{l}363 \text { vs. } 365 \\
\text { vs. } 365\end{array}$ & $\begin{array}{l}47.20 \% \text { vs. } \\
51.20 \% \text { vs. } \\
50.30 \%, p=n s\end{array}$ & $\begin{array}{l}6.0 \mathrm{mo} \text { vs. } 5.8 \mathrm{mo} \text { vs. } \\
5.5 \mathrm{mo}, p=0.7633\end{array}$ & $\begin{array}{l}10.9 \mathrm{mo} \text { vs. } 9.9 \mathrm{mo} \text { vs. } \\
9.9 \mathrm{mo}, p=0.4560\end{array}$ \\
\hline INTACT 2 [16] & III-IV & $\begin{array}{l}\text { Carboplatin + Paclitaxel } \\
(C P) \text { vs. CP + Gefitinib } \\
250 \text { mg/d vs. CP + } \\
\text { Gefitinib } 500 \text { mg/d }\end{array}$ & $\begin{array}{l}345 \text { vs. } 345 \\
\text { vs. } 347\end{array}$ & $\begin{array}{l}28.70 \% \text { vs. } \\
30.40 \% \text { vs. } \\
30.00 \%, p=n s\end{array}$ & $\begin{array}{l}5.0 \mathrm{mo} v s .5 .3 \mathrm{mo} v s . \\
4.6 \mathrm{mo}, p=0.0562\end{array}$ & $\begin{array}{l}9.9 \mathrm{mo} v \mathrm{vs} .9 .8 \mathrm{mo} \text { vs. } \\
8.7 \mathrm{mo}, p=0.6385\end{array}$ \\
\hline TRIBUTE [17] & IIIB-IV & $\begin{array}{l}\text { Carboplatin + Paclitaxel } \\
(C P) \text { vs. CP + Erlotinib; } \\
\text { followed by Erlotinib } \\
\text { maintenance }\end{array}$ & 540 vs. 539 & $\begin{array}{l}19.30 \% \text { vs. } \\
21.50 \% \\
p=0.36\end{array}$ & $\begin{array}{l}4.9 \mathrm{mo} \text { vs. } 5.1 \mathrm{mo}, \\
p=0.36\end{array}$ & $\begin{array}{l}10.5 \mathrm{mo} \text { vs. } 10.6 \mathrm{mo}, \\
p=0.95\end{array}$ \\
\hline $\begin{array}{l}\text { IPASS [18] Non- } \\
\text { smokers or former } \\
\text { light smokers with } \\
\text { adenocarcinoma }\end{array}$ & IIIB-IV & $\begin{array}{l}\text { Carboplatin + Paclitaxel } \\
\text { vs. Gefitinib }\end{array}$ & 608 vs. 609 & $\begin{array}{l}32.20 \% \text { vs. } \\
43.00 \% \\
p<0.001\end{array}$ & $\begin{array}{l}6.7 \% \text { vs. } 24.9 \% \text { at } \\
1 \text { year, } p<0.001\end{array}$ & 17.3 mo vs. $18.6 \mathrm{mo}$ \\
\hline $\begin{array}{l}\text { WJTOG3405 [19] } \\
\text { Sensitive EGFR } \\
\text { mutation + only }\end{array}$ & $\begin{array}{l}\text { IIIB-IV, } \\
\text { postoperative } \\
\text { recurrent }\end{array}$ & $\begin{array}{l}\text { Gefitinib vs. Cisplatin }+ \\
\text { Docetaxel }\end{array}$ & 86 vs. 86 & $\begin{array}{l}62.10 \% \text { vs. } \\
32.20 \% \\
p<0.0001\end{array}$ & $\begin{array}{l}9.2 \mathrm{mo} v \mathrm{vs} .6 .3 \mathrm{mo}, \\
p<0.0001\end{array}$ & $\begin{array}{l}30.9 \text { mo vs. not } \\
\text { reached, } p=0.211\end{array}$ \\
\hline $\begin{array}{l}\text { OPTIMAL [20] } \\
\text { Sensitive EGFR } \\
\text { mutation + only }\end{array}$ & IIIB-IV & $\begin{array}{l}\text { Erlotinib vs. Carboplatin } \\
+ \text { Gemcitabine }\end{array}$ & 82 vs. 72 & $\begin{array}{l}83 \% \text { vs. } 36 \% \\
p<0.0001\end{array}$ & $\begin{array}{l}13.1 \mathrm{mo} \text { vs. } 4.6 \mathrm{mo}, \\
p<0.0001\end{array}$ & \\
\hline $\begin{array}{l}\text { NEJ002 [21] } \\
\text { Sensitive EGFR } \\
\text { mutation + only }\end{array}$ & $\begin{array}{l}\text { IIIB-IV, } \\
\text { postoperative } \\
\text { recurrent }\end{array}$ & $\begin{array}{l}\text { Gefitinib vs. Carboplatin/ } \\
\text { Paclitaxel }\end{array}$ & 114 vs. 114 & $\begin{array}{l}73.7 \% \text { vs. } \\
30.7 \%, p<0.001\end{array}$ & $\begin{array}{l}10.8 \mathrm{mo} \text { vs. } 5.4 \mathrm{mo}, \\
p<0.001\end{array}$ & $\begin{array}{l}27.7 \text { mo vs. } 26.6 \mathrm{mo}, \\
p=0.483\end{array}$ \\
\hline $\begin{array}{l}\text { EURTAC [22] } \\
\text { Sensitive EGFR } \\
\text { mutation + only }\end{array}$ & IIIB-IV & $\begin{array}{l}\text { Erlotinib vs. Platinum } \\
\text { based chemotherapy }\end{array}$ & 86 vs. 87 & $\begin{array}{l}63 \% \text { vs. } 18 \% \\
p<0.001\end{array}$ & $\begin{array}{l}9.7 \mathrm{mo} \text { vs. } 5.2 \mathrm{mo} \\
p<0.0001\end{array}$ & $\begin{array}{l}19.3 \text { mo vs. } 19.5 \mathrm{mo}, \\
p=0.87\end{array}$ \\
\hline TORCH [23] & IIIB-IV & $\begin{array}{l}\text { Erlotinib vs. Cisplatin/ } \\
\text { Gemcitabine as } 1^{\text {st }} \text { line } \\
\text { treatment, and the } \\
\text { opposite as } 2^{\text {nd }} \text { line } \\
\text { therapy }\end{array}$ & 373 vs. 371 & $\begin{array}{l}20.3 \% \text { vs. } \\
32.6 \% ; 2^{\text {nd }} \text { line } \\
\text { Erlotinib vs. } 2^{\text {nd }} \\
\text { line chemo: } \\
4.7 \% \text { vs. } 10.5 \% \text {; } \\
p<0.001\end{array}$ & $6.4 \mathrm{mo} \mathrm{vs} .8 .9 \mathrm{mo}$ & $8.7 \mathrm{mo}$ vs. $11.6 \mathrm{mo}$ \\
\hline \multicolumn{7}{|l|}{ Cetuximab } \\
\hline FLEX [33] & IIIB-IV & $\begin{array}{l}\text { Cisplatin + Vinorelbine } \\
\text { (CV) vs. CV + Cetuximab }\end{array}$ & 568 vs. 557 & $\begin{array}{l}29 \% \text { vs. } 35 \% \\
p=0.010\end{array}$ & $\begin{array}{l}4.8 \mathrm{mo} \text { vs. } 4.8 \mathrm{mo} \\
p=0.39\end{array}$ & $\begin{array}{l}10.1 \mathrm{mo} \text { vs. } 11.3 \mathrm{mo}, \\
p=0.044\end{array}$ \\
\hline BMS099 [34] & IIIB-IV & $\begin{array}{l}\text { Carboplatin + Taxane } \\
\text { (CT) vs. CT + Cetuximab }\end{array}$ & 338 vs. 338 & $\begin{array}{l}17.20 \% \text { vs. } \\
25.70 \% \\
p=0.007\end{array}$ & $\begin{array}{l}4.24 \text { mo vs. } 4.40 \mathrm{mo}, \\
p=0.2358\end{array}$ & $\begin{array}{l}8.38 \mathrm{mo} \text { vs. } 9.69 \mathrm{mo}, \\
p=0.169\end{array}$ \\
\hline
\end{tabular}


to increased PFS, and EGFR expression was significantly correlated with PFS [30]. In addition, EGFR mutation $s$ were associated a large improvement in PFS with the addition of Erlotinib as maintenance therapy.

\section{Cetuximab combined chemotherapy as first line treatment}

While a large amount of clinical evidence on how to most effectively incorporate EGFR TKIs into the management of advanced NSCLC has been generated, the clinical experience with mono-clonal antibodies in advanced NSCLC is just emerging in recent years. Cetuximab as a single agent generated minimal response in advanced NSCLC [31]. However, its addition to first line Cisplatin and Vinorelbine was shown to increase tumor response in stage IIIB-IV NSCLC when compared with the same chemotherapy alone in a phase II study [32]. Two randomized phase III studies on the combination of Cetuximab with chemotherapy as first line treatment have been reported subsequently [33,34]. In the FLEX study, which randomized 1125 patients with stage IIIB-IV NSCLC to Cetuximab delivered concurrently with up to 6 cycles of Cisplatin and Vinorelbine and until disease progression and the same chemotherapy alone, the addition of Cetuximab led to significantly increased ORR (35\% vs. 29\%, $p=0.010)$ and median survival (11.3 vs. 10.1 months, $p=0.044)$. Only $10 \%$ of the patients experienced an acne-like rash on the Cetuximab arm, and no >grade 3 acne-like rash was observed in this study. The superior response associated with the addition of Cetuximab to first line chemotherapy was confirmed in another phase III randomized study (BMS 099) randomizing 676 patients to Carboplatin, plus a taxane or Caboplatin-based chemotherapy combined with Cetuximab, which is given till disease progression. However, no survival benefit was demonstrated in that study (Table 1 ). Only $10.5 \%$ grade 3 or 4 acne-like rash was observed in this study.

\section{Patient selection for EGFR TKIs or mAb in NSCLC: the current evidence}

Given the studies summarized above, it is clear that patient selection for EGFR TKI or mAb is essential as they are only effective in a group of patients with certain biological traits. The association between EGFR mutations and the efficacy of SM TKIs in phase 3 randomized studies is direct evidence for this. As a result, predictive biomarkers for efficacy of TKI or mAb treatment have been sought in patients from various phase II/III and prospective studies (Table 2). Among studies of a TKI alone as $1^{\text {st }}, 2^{\text {nd }}, 3^{\text {rd }}$ line treatment or maintenance therapy, EGFR mutation was identified most frequently and consistently as a predictor of tumor response, and survival outcome [35-40]. However, KRAS mutation, pAKT and HER-2 expression were also found to be possible predictive biomarkers for survival outcome following TKI treatment in selected studies [36-38]. When used in combination with chemotherapy, EGFR mutation and KRAS mutation and EGFR gene copy number are identified to be potential predictive biomarkers for TKI efficacy $[41,42]$. It is also found that the EGFR gene copy number predictive value depended on the EGFR mutation status in the IPASS trial (Table 2).

Among phase II-III studies evaluating the efficacy of Cetuximab, only the EGFR gene copy number and EGFR mutation were found to be potential biomarkers for this mAb's efficacy (Table 2). Among the two large phase 3 randomized studies (BMS099 \& FLEX trials), the EGFR mutation was the only biomarker found to be predictive of superior survival after either chemotherapy combined with Cetuximab or chemotherapy alone in the FLEX trial $[44,45]$.

Based on the evidence generated from the studies described thus far, the EGFR mutation status appear to be the most consistently found predictive biomarker for EGFR TKI or mAb efficacy in advanced NSCLC while other potential markers, such as KRAS mutation and EGFR gene copy number, need to be further evaluated in larger cohort of patients in the future.

\section{Potential role of EGFR TKI and $\mathrm{mAb}$ as radiosensitizers}

The EGFR has been known to play a key role in the activation of DNA repair and anti-apoptotic proteins, as well as tumor cell repopulation after irradiation $[8,46]$. Upon irradiation, increased levels of EGFR autophosphorylation has been observed, leading to the activation of the EGFR and its downstream signaling pathways [8]. Furthermore, its expression has been shown to be correlated with radio-resistance and poor outcome after radiotherapy in pre-clinical and clinical studies $[8,47]$. Thus, adding an EGFR TKI or mAb to inhibit EGFR activation induced by irradiation become a very sound strategy in enhancing the radiocurability of EGFR over-expressing cancers. This has been successfully validated in the treatment of locally advanced squamous cell carcinoma of the head and neck. In a randomized phase 3 study comparing concurrent Cetuximab plus radiotherapy and radiotherapy alone, a 9.2\% 5 year overall survival benefit ( $45.6 \%$ vs. $36.4 \%, p<0.05$ ) was observed with the addition of cetuximab [48]. As an EGFR overexpression cancer, locally advanced NSCLC has been treated with concurrent chemo-radiation with a 5-year survival of approximately $15 \%$, and 5 year loco-regional control of approximately $70 \%$ based on major randomized studies [49]. Despite the poor outcome observed, concurrent chemoradiation is often associated with significant toxicity, which prevents further radiation dose 
Table 2 Predictive biomarkers in the major clinical trials

\begin{tabular}{|c|c|c|}
\hline Study & Study arms & Predictive biomarkers \\
\hline \multicolumn{3}{|l|}{$T K I$} \\
\hline INTEREST [35] & $\begin{array}{l}\text { Gefitinib vs. Docetaxel in previous treated } \\
\text { patients }\end{array}$ & $\begin{array}{l}\text { EGFR mutation predicted for longer PFS and higher ORR ( } p \\
<0.05 \text { ) and high EGFR copy number predicted for higher ORR ( } p \\
<0.05 \text { ) with Gefinitib vs. Docetaxel. KRAS mutation was not } \\
\text { predictive for response or survival. }\end{array}$ \\
\hline SATURN [36] & $\begin{array}{l}\text { Maintenance Erlotinib vs. observation after } \\
1^{\text {st }} \text { line chemotherapy }\end{array}$ & $\begin{array}{l}\text { EGFR IHC, EGFR FISH, KRAS mutation and EGFR CA-SSR1 repeat } \\
\text { length status did not predict for drug response. EGFR mutation } \\
\text { predicted for PFS, and OS benefit after Erlotinib treatment KRAS } \\
\text { mutation predicted for poor PFS. }\end{array}$ \\
\hline Italian Phase II study [37] & EGFR-TKI as $2^{\text {nd }}$ line treatment & $\begin{array}{l}\text { PAKT and HER-2 expression are the only independent predictors } \\
\text { of PFS and OS }\end{array}$ \\
\hline ERMETIC [38] & EGFR TKI as $1^{\text {st }}, 2^{\text {nd }}$, or $3^{\text {rd }}$ line treatment & $\begin{array}{l}\text { Median PFS: EGFR mutant } 8.4 \text { mo, EGFR wild type } 2.3 \text { mo, KRAS } \\
\text { mutant } 1.9 \text { mo, } p=0.001 \text {. Median OS: EGFR mutant } 14.4 \text { mo, } \\
\text { EGFR wild type } 5.3 \text { mo, KRAS mutant } 4.1 \text { mo, } p=0.004 \text {. }\end{array}$ \\
\hline PUMC prospective study [39] & Gefitinib after failing $1^{\text {st }}$ line chemotherapy & $\begin{array}{l}\text { EGFR mutation is the only independent predictor of tumor } \\
\text { response. }\end{array}$ \\
\hline IDEAL \& INTACT trials [40] & $\begin{array}{l}\text { IDEAL trials: phase II studies on Gefitinib as } \\
2^{\text {nd }} \text { line treatment; INTACT trials: phase III } \\
\text { studies investigating the benefit of adding } \\
\text { Gefitinib to chemotherapy as } 1^{\text {st }} \text { line } \\
\text { treatment }\end{array}$ & $\begin{array}{l}\text { EGFR mutation predicted for increased response to Gefitinib in } \\
\text { IDEAL trials, but not in the INTACT trials. KRAS mutation, PTEN } \\
\text { mutation or expression and p53 expression not associated with } \\
\text { clinical response to Gefitinib in the IDEAL trials. }\end{array}$ \\
\hline TRIBUTE [41] & $\begin{array}{l}\text { Carboplatin + Taxol (CT) vs. CT + Erlotinib; } \\
\text { followed by Erlotinib maintenance }\end{array}$ & $\begin{array}{l}\text { EGFR mutations (13\%) in EGFR exons } 18 \text { through } 21 \text { were } \\
\text { predictive of OS overall; and superior response to } C T \text { + Erlotinib } \\
(p<0.01) \text {. KRAS mutations }(21 \%) \text { at KRAS exon } 2 \text { was associated } \\
\text { with decreased TTP and OS in the } C T+\text { Erlotinib arm. }\end{array}$ \\
\hline $\begin{array}{l}\text { IPASS (Fukuoka JCO 11) [42] } \\
\text { Non-smokers or former light } \\
\text { smokers with adenocarcinoma }\end{array}$ & Carboplatin + Taxol vs. Gefitinib & $\begin{array}{l}\text { High EGFR gene copy number was associated with increased } \\
\text { PFS and ORR after Gefitinib vs. Carbo/Taxol. However, it } \\
\text { predicted for poorer PFS in the absence of EGFR mutation. EGFR } \\
\text { mutation at Exon } 19 \text { and } 21 \text { predicted for superior PFS and ORR } \\
\text { after Gefitinib. }\end{array}$ \\
\hline \multicolumn{3}{|l|}{ Cetuximab } \\
\hline SWOG 0342 [43] & $\begin{array}{l}\text { Carbo/Taxol + Cetuximab vs. Carbo/Taxol; } \\
\text { Both followed by Cetuximab for } 1 \text { year }\end{array}$ & $\begin{array}{l}\text { Increased EGFR gene copy numbers is associated with superior } \\
\text { PFS and OS }(p<0.05)\end{array}$ \\
\hline BMS099 [44] & $\begin{array}{l}\text { Carboplatin + Taxane (CT) vs. CT + } \\
\text { Cetuximab }\end{array}$ & $\begin{array}{l}\text { EGFR FISH, EGFR IHC, KRAS mutations and EGFR mutations did } \\
\text { not predict for ORR, PFS, or OS benefit with the addition of } \\
\text { Cetuximab }\end{array}$ \\
\hline FLEX [45] & $\begin{array}{l}\text { Cisplatin + Vinorelbine (CV) vs. CV + } \\
\text { Cetuximab }\end{array}$ & $\begin{array}{l}\text { KRAS }(19 \%) \text {, EGFR FISH + (37\%), PTEN negativity }(35 \%) \text { were of no } \\
\text { predictive value. EGFR mutation (15\%) predicted for improved } \\
\text { OS in both arms }(p<0.05) \text {. }\end{array}$ \\
\hline
\end{tabular}

escalation. Therefore, combining an EGFR TKI or mAb with radiotherapy or chemoradiation can potentially be a more effective strategy in the treatment of locally advanced NSCLC.

In pre-clinical studies of NSCLC, radiosensitizing effects of both EGFR TKIs and mAbs have been reported [13,50-54]. This has led to a series of studies combining TKIs and mAbs to the EGFR with radiotherapy or chemoradiation. Combining a TKI with radiotherapy or chemoradiation has been shown to be feasible in several studies [55-63]. As shown in Table 3, median survival of $>20$ months was achieved in several studies $[58,59,62,63]$. As shown by Wang et al., a concurrent TKI and radiotherapy to 70 Gy in stage III-IV patients achieved a median survival of 21.8 months, which is at least comparable to what has been reported after concurrent chemoradiation $[58,64,65]$. However, the addition of chemotherapy to TKI and radiotherapy may possibly increase the risk of fatal pneumonitis and hematologic toxicities [57,59]. Furthermore, the use of concurrent chemotherapy, radiotherapy and EGFR TKI may not be better than combined TKI and radiotherapy [61]. Disappointing survival outcome is again demonstrated in another phase II study investigating induction chemotherapy followed by concurrent chemotherapy, TKI, and radiotherapy to 74 Gy [60]. This implies the potential risk of increased toxicity when combining chemotherapy, EGFR TKI and radiotherapy; and also the importance of drug treatment sequencing for chemotherapy and TKI. As shown in a different study, which delivers 1 dose of chemotherapy followed by subsequent doses of TKI each week with radiotherapy, median 
Table 3 EGFR tyrosine kinase inhibitors or mono-clonal antibodies combined with radiotherapy

\begin{tabular}{|c|c|c|c|c|c|c|c|}
\hline Study & Study scheme & Stage & \#Pts & RT Dose (Gy) & ORR & Median PFS & Median OS \\
\hline \multicolumn{8}{|l|}{ TKI } \\
\hline Okamoto et al [55] & $\begin{array}{l}\text { Gefitinib } \times 14 \text { days, then given } \\
\text { concurrently with RT }\end{array}$ & III & 9 & 60 Gy & $\begin{array}{l}4 \text { pts who } \\
\text { completed } \\
\text { with PR }\end{array}$ & & $\begin{array}{l}2 \text { pts with EGFR } \\
\text { mutations lived } \\
>5 \text { yrs. }\end{array}$ \\
\hline Choong et al [56] & $\begin{array}{l}\text { Erlotinib + Cisplatin + Etoposide + } \\
\text { RT then docetaxel } \times 3 \text { cycles vs. } \\
\text { Carboplatin + Paclitaxel , then } \\
\text { Erlotinib + Carboplatin + Paclitaxel } \\
\text { + RT }\end{array}$ & III & 17 vs. 17 & 66 Gy & $\begin{array}{l}65 \% \text { vs. } 59 \% \\
p=n s\end{array}$ & $\begin{array}{l}13 \% \text { vs. } 15 \% \text { at } \\
3 \text { yrs, } p=0.9168\end{array}$ & $\begin{array}{l}11 \text { mo vs. } 15 \mathrm{mo}, \\
p=0.8979\end{array}$ \\
\hline Rothschild et al [57] & $\begin{array}{l}\text { Erlotinib + RT or Erlotinib + } \\
\text { Cisplatin + RT }\end{array}$ & III & 14 & 63 Gy & $21.4 \%$ & $6.0 \mathrm{mo}$ & $12.7 \mathrm{mo}$ \\
\hline Wang et al [58] & Gefitinib or Erlotinib + RT & III/IV & 26 & 70 Gy & $96 \%$ & $10.2 \mathrm{mo}$ & $21.8 \mathrm{mo}$ \\
\hline Center et al [59] & Gefitinib + Docetaxel + RT & III & 16 & 70 Gy & & $7.1 \mathrm{mo}$ & $21.0 \mathrm{mo}$ \\
\hline $\begin{array}{l}\text { Stinchcombe et al } \\
\text { [60] }\end{array}$ & $\begin{array}{l}\text { Carboplatin + Irinotecan + Taxol } \\
\text { followed by Carboplatin/Taxol + } \\
\text { Gefitinib + RT }\end{array}$ & III & 23 & 74 Gy & $24 \%$ & $9 \mathrm{mo}$ & $16 \mathrm{mo}$ \\
\hline Ready et al [61] & $\begin{array}{l}\text { Carboplatin/Taxol } \times 2 \text { cycles } \pm \\
\text { Gefitinib then Gefinitib }+ \text { RT vs. } \\
\text { Carboplatin/Taxol + Gefitinib }+ \text { RT; } \\
\text { both groups are given Gefitinib } \\
\text { after RT if w/o severe radiation } \\
\text { toxicity. }\end{array}$ & III & 21 vs. 39 & 66 Gy & $\begin{array}{l}52.40 \% \text { vs. } \\
81.60 \% \\
p=0.034\end{array}$ & $\begin{array}{l}13.4 \text { mo vs. } 9.2 \\
\text { mo }\end{array}$ & $\begin{array}{l}19.0 \text { mo vs. } 13.0 \\
\text { mo }\end{array}$ \\
\hline Chang et al [62] & $\begin{array}{l}\text { Upfront TKI, followed by TKI+ } \\
\text { multitarget IMRT with helical } \\
\text { tomotherapy }\end{array}$ & IIIB-IV & 25 & $\begin{array}{l}40-50 \text { Gy in } \\
16-20 \text { daily } \\
\text { fractions. }\end{array}$ & $84 \%$ & $16 \mathrm{mo}$ & $\begin{array}{l}\text { Not reached, } 3 \text { yr } \\
\text { OS } 62.5 \%\end{array}$ \\
\hline Komaki et al [63] & $\begin{array}{l}\text { Carboplatin + Paclitaxel on } \\
\text { Monday, followed by Erlotinib for } \\
\text { the rest of the week combined } \\
\text { with RT; Consolidative } \\
\text { Carboplatin + Paclitaxel x } 2 \text { cycles } \\
\text { were then given }\end{array}$ & III & 46 & $\begin{array}{l}63 \mathrm{~Gy} / 35 \\
\text { daily fractions }\end{array}$ & $80 \%$ & $14.5 \mathrm{mo}$ & $34.1 \mathrm{mo}$ \\
\hline \multicolumn{8}{|c|}{ Cetuximab or Nimotuzumab } \\
\hline Hughes et al [66] & $\begin{array}{l}\text { Platinum based chemotherapy } \\
\text { followed by Cetuximab + RT }\end{array}$ & III-IV & 12 & 64 Gy & $70 \%$ & & \\
\hline Choi et al [67] & $\begin{array}{l}\text { Weekly Nimotuzumab + RT, then } \\
\text { q2 weeks till progression }\end{array}$ & IIB-IV & 15 & $\begin{array}{l}30 \text { or } 36 \mathrm{~Gy} \\
\text { in } 3 \mathrm{~Gy} \\
\text { fractions }\end{array}$ & $46.70 \%$ & $5.4 \mathrm{mo}$ & $9.8 \mathrm{mo}$ \\
\hline Bebb et al [68] & $\begin{array}{l}\text { Weekly Nimotuzumab }+R T \text {, then } \\
\text { q2 weeks till progression }\end{array}$ & III-IV & 18 & $\begin{array}{l}30 \text { or } 36 \mathrm{~Gy} \\
\text { in } 3 \mathrm{~Gy} \\
\text { fractions }\end{array}$ & $66 \%$ & $4 \mathrm{mo}$ & $15 \mathrm{mo}$ \\
\hline Govindan et al [69] & $\begin{array}{l}\text { Carboplatin + Pemetrexed + RT vs. } \\
\text { Carboplatin + Pemetrexed + } \\
\text { Cetuximab + RT }\end{array}$ & III & 48 vs. 53 & 70 Gy & $\begin{array}{l}77 \% \text { vs. } 72 \%, \\
p=n s\end{array}$ & $\begin{array}{l}12.6 \text { mo vs. } 12.3 \\
\text { mo, } p=n s\end{array}$ & $\begin{array}{l}21.2 \text { mo vs. } 25.2 \\
\text { mo, } p=n s\end{array}$ \\
\hline Jensen et al [70] & $\begin{array}{l}\text { Cetuximab }+ \text { RT followed by } \\
\text { maintemance Cetuximab }\end{array}$ & III & 30 & 66 Gy & & $8.5 \mathrm{mo}$ & 19.6 mo \\
\hline Hallqvist et al [71] & $\begin{array}{l}\text { Cisplatin + Docetaxel followed by } \\
\text { Cetuximab + RT }\end{array}$ & III & 75 & 68 Gy & $23.5 \%$ & & $17 \mathrm{mo}$ \\
\hline $\begin{array}{l}\text { Blumenschein et al } \\
\text { [72] }\end{array}$ & $\begin{array}{l}\text { Carboplatin + Taxol + Cetuximab } \\
+ \text { RT followed Carboplatin + Taxol } \\
+ \text { Cetuximab }\end{array}$ & III & 87 & 63 Gy & $62 \%$ & $12 \mathrm{mo}$ & $22.7 \mathrm{mo}$ \\
\hline
\end{tabular}

survival appears to be noticeably improved when treatment was delivered in this fashion [63]. Due to the size of the studies, predictive biomarkers have not been consistently identified. However, long term survival and excellent overall survival have been reported in patients who harbor EGFR mutations (deletion on exon 19) and who responded to upfront TKI [55,62]. Again, suggesting the importance of patient selection in the application of TKI's as radiosensitizers.

A limited number of studies investigating the radiosensitizing effects of a mAb have been reported as well (Table 3). Among them, several have translated into 
median survival rates comparable to what has observed after concurrent chemoradiation [64,65,69-72]. The addition of Cetuximab or Nimotuzumab to radiotherapy or chemoradiation appear to be well tolerated with > grade 3 pneumonitis reported only in cases which had excessive amount of radiation dose to the normal lung tissue [66-72]. The results from RTOG 0617, a confirmatory intergroup trial evaluating the addition of cetuximab to chemoradiation in stage III NSCLC are eagerly anticipated.

\section{Future directions}

The findings from large phase III randomized studies demonstrated that patient selection is essential in the application of EGFR TKI in the treatment of stage IIIBIV NSCLC. Patients who harbor a activating EGFR mutation usually responds very well to treatments including EGFR TKI or mAb alone or combined with chemotherapy and/or radiotherapy [35,36,38-42,45,55]. This further confirmed previous findings in phase II studies, which demonstrated higher response rates to EGFR TKIs in patients with activating EGFR mutations than that found after platinum-based chemotherapy, but very poor response in patients with only wild type EGFR expression [73]. The response associated with EGFR mutations is thought to be due mainly to an "addictive" dependence of tumor cells on the EGFR signaling pathway for survival [73]. However, response to the EGFR TKIs may be short lived due possibly to a secondary mutation in the EGFR (T790M), or increased signaling through pathways downstream to the EGFR without its activation $[26,27,74]$. T790M may increase the GTP affinity in the tyrosine kinase domain of the EGFR, or hindrance to TKI binding to the tyrosine kinase domain [75,76]. As shown by Su et al., T790M appears to be more prevalent in patients who has not had any TKI treatment $(25.2 \%$ $31.5 \%)$, and it becomes even more prevalent after TKI treatment (83.3\%) [76]. This finding suggests that TKI treatment selects for NSCLC cells with T790M mutation, and new strategy needs to be developed to overcome T790M related resistance. Further shown by $\mathrm{Su}$ et al., NSCLC patients who harbor mutations in exons 19, 20 , and 21 can still benefit from TKI, with superior PFS to that in patients without any of these mutations [76]. Therefore, TKI is still indicated in patients with activating EGFR mutations on exons 19, and 21 with or without T790M identified while additional treatment should be added to overcome resistance due to T790M. Resistance due to T790M can potentially overcome by second generation irreversible EGFR TKIs, which appear to be well tolerated in early clinical studies [5]. Although did not demonstrated an overall survival benefit, Afatinib, an irreversible EGFR, Her-2, and ErbB4 blocker has led to significant PFS in patients who progressed after a 12 week course of Gefitinib or Erlotinib when compared to placebo in a phase $2 b / 3$ trial [77]. This agent has been shown to be highly effective in adenocarcinoma harboring activating mutations on exon 19 and 21 when compared with Cisplatin and Pemetrexed (CP) approximately doubling the response rate and PFS achieved with $\mathrm{CP}$, which makes first line treatment of choice in this cohort of patients [78].

Increased signaling through the PI3K pathway through MET-trigger ErbB3 signaling in TKI-resistant NSCLC cells overexpressing MET oncogene has been shown to be a classic example of acquired resistance through bypassing the EGFR, which can be overcome through dual EGFR and MET inhibition [74]. This strategy has been shown to be effective in pre-clinical studies. As shown by Nakagawa et al., WZ4002, a mutant EGFRTKI, and E7050, a mutant selective dual inhibitor of Met and VEGFR-2, were able to inhibit tumor growth in Erlotinib resistant NSCLC cells in vitro and in vivo when given together with successful inhibition of the EGFR, Met, and their downstream PI3K-AKT pathway [79]. The combination of $2^{\text {nd }}$ generation TKIs and MET inhibitors with radiotherapy and/or chemotherapy still need to be further investigated in future studies. In addition to MET signaling stimulated PI3K signaling, BRAF mutation in the RAS-RAF-MEK-MAPK pathway, and loss of PTEN expression may also lead to acquired resistance to an EGFR TKI $[80,81]$.

As a another potential predictive biomarker for a lack of response to EGFR TKIs in NSCLC, KRAS mutation was only shown to be associated with treatment outcome in selected studies $[38,41]$. It is observed in approximately $30 \%$ of adenocarcinomas [82]. Its mutated form often leads to a gain of function in its downstream signaling pathway, in particular, the Raf-MEK-ERK pathway. This subsequently increases MAPK signaling and tumor cell proliferation. In addition, the mutated KRAS also leads to increased TGF- $\alpha$ expression, which further stimulates the EGFR [82]. Although not consistently demonstrated in major randomized phase III studies, KRAS mutations was found to be significantly associated with an absence of response to TKIs in NSCLC in a meta-analysis of 17 studies [83]. The role of KRAS mutation in major studies evaluating the efficacy of Cetuximab has not been clearly shown. Thus, the role of KRAS mutation as a predictive biomarker for poor response to EGFR inhibition needs to be further elucidated.

Due to differences of the EGFR inhibition mechanism by the $\mathrm{mAb}$, which can generate antibody dependent cellular cytotoxicity; and TKIs ability to inhibit multiple types of ErbB receptors, the role of dual blockade should be explored further in the clinical as they have been shown to increase the potency of EGFR inhibition in vitro and in vivo $[1,84]$. Targeting downstream signaling pathways 
to the EGFR directly can also be a potential approach of augmenting the antitumor activity of radiotherapy and chemotherapy with EGFR inhibitors [85,86]. At last, simultaneously blocking the EGFR, its downstream signaling pathway, such as the PI3K pathway, and parallel signaling pathways alone, or combined with chemotherapy and radiotherapy, may lead to maximal antitumor activity and warrants further investigation in the future.

\section{Competing interests}

The authors declare that they have no competing interests.

\section{Authors' contributions}

$A C, S R$ and WT have generated the idea of conducting this review and AC has writing the manuscript with SR and WT reviewed, given suggestions on modifications, and approved the final version. All authors read and approved the final manuscript.

\section{Author details}

'Department of Radiation Oncology, West Virginia University, Morgantown, WV 26506, USA. ${ }^{2}$ Mary-Babb Randolph Cancer Center, West Virginia University, Morgantown, WV 26506, USA. ${ }^{3}$ Department of Hematology and Oncology, West Virginia University, Morgantown, WV 26506, USA.

Received: 9 October 2012 Accepted: 12 October 2012

Published: 16 January 2013

\section{References}

1. Mendelsohn J, Baselga J: Status of epidermal growth factor receptor antagonists in the biology and treatment of cancer. J Clin Oncol 2003, 21:2787-2799

2. Yoshida T, Zhang G, Haura EB: Targeting epidermal growth factor receptor: Central signaling kinase in lung cancer. Biochem Pharmacol 2010, 80:613-623.

3. Ono M, Kuwano M: Molecular mechanisms of epidermal growth factor receptor (EGFR) activation and response to gefitinib and other EGFRtargeting drugs. Clin Cancer Res 2006, 12:7242-7251.

4. Cohen S: Isolation of a mouse submaxillary gland protein accelerating incisor eruption and eyelid opening in the new-born animal. $J$ Biol Chem 1962, 237:1555-1562.

5. Ausborn NL, Le QT, Bradley JD, et al: Molecular profiling to optimize treatment in non-small cell lung cancer: a review of potential molecular targets for radiation therapy by the translational research program of the Radiation Therapy Oncology Group. Int J Radiat Oncol Biol Phys 2012, 83:e453-e464.

6. Mendelsohn J, Baselga J: The EGF receptor family as targets for cancer therapy. Oncogene 2000, 19:6550-6565.

7. Harari PM, Huang SM: Combining EGFR inhibitors with radiation or chemotherapy: will preclinical studies predict clinical results? Int I Radiat Oncol Biol Phys 2004, 58:976-983.

8. Milas L, Fan Z, Andratschke NH, Ang KK: Epidermal growth factor receptor and tumor response to radiation: in vivo preclinical studies. Int I Radiat Oncol Biol Phys 2004, 58:966-971.

9. Raben D, Helfrich B, Bunn PA: Targeted therapies for non-small-cell lung cancer: Biology, rationale, and preclinical results from a radiation oncology perspective. Int I Radiat Oncol Biol Phys 2004, 59:S27-38.

10. Cappuzzo F, Hirsch FR, Rossi E, et al: Epidermal growth factor receptor gene and protein and gefitinib sensitivity in non-small cell lung cancer. J Natl Cancer Inst 2005, 97:643-655.

11. Hirsch FR, Varella-Garcia M, Bunn PA Jr, et al: Epidermal growth factor receptor in non-small cell lung carcinomas: correlation between gene copy number and protein expression and impact on prognosis. $J$ Clin Oncol 2003, 21:3798-3807.

12. Herbst RS, Bunn PA: Targeting the epidermal growth factor receptor in non-small cell lung cancer. Clin Cancer Res 2003, 9:5813-5824.

13. Raben D, Helfrich B, Chan DC, et al: The effects of cetuximab alone and in combination with radiation and/or chemotherapy in lung cancer. Clin Cancer Res 2005, 11:795-805.
14. Cascone T, Morelli MP, Ciardiello F: Small molecule epidermal growth factor receptor (EGFR) tyrosine kinase inhibitors in non-small cell lung cancer. Ann Oncol 2006, Suppl 2:ii46-ii48.

15. Giaccone G, Herbst RS, Manegold C, et al: Gefitinib in combination with gemcitabine and cisplatin in advanced non-small-cell lung cancer: a phase III trial-INTACT 1. J Clin Oncol 2004, 22:777-784.

16. Herbst RS, Giaccone G, Schiller JH, et al: Gefitinib in combination with paclitaxel and carboplatin in advanced non-small-cell lung cancer: a phase III trial-INTACT 2. J Clin Oncol 2004, 22:785-794.

17. Herbst RS, Prager D, Hermann R, et al: TRIBUTE: a phase III trial of erlotinib hydrochloride (OSI-774) combined with carboplatin and paclitaxel chemotherapy in advanced non-small-cell lung cancer. J Clin Oncol 2005, 23:5892-5899.

18. Mok TS, Wu YL, Thongprasert S, et al: Gefitinib or carboplatin-paclitaxel in pulmonary adenocarcinoma. N Engl J Med 2009, 361:947-957.

19. Mitsudomi T, Morita S, Yatabe Y, et al: Gefitinib versus cisplatin plus docetaxel in patients with non-small-cell lung cancer harbouring mutations of the epidermal growth factor receptor (WJTOG 3405): an open label, randomised phase 3 trial. Lancet Oncol 2010, 11:121-128.

20. Zhou C, Wu Y, Chen G, et al: Erlotinib versus chemotherapy as first-line treatment for patients with advanced EGFR mutation-positive non-smallcell lung cancer (OPTIMAL, CTONG-0802): a multicentre, open-label, randomised, phase 3 study. Lancet Oncol 2011, 12:735-742.

21. Inoue A, Kobayashi K, Maemondo $M$, et al: Updated overall survival results from a randomized phase III trial comparing gefitinib with carboplatinpaclitaxel for chemo-naïve non-small cell lung cancer with sensitive EGFR gene mutations (NEJ002). Ann Oncol 2012. In press.

22. Rosell R, Carcereny E, Gervais $R$, et al: Erlotinib versus standard chemotherapy as first-line treatment for European patients with advanced EGFR mutation-positive non-small-cell lung cancer (EURTAC): a multicentre, open-label, randomised phase 3 trial. Lancet Oncol 2012, 13:239-246.

23. Gridelli C, Ciardiello F, Gallo C, et al: First-line erlotinib followed by secondline cisplatin-gemcitabine chemotherapy in advanced non-small-cell lung cancer: the TORCH randomized trial. J Clin Oncol 2012, 30:3002-3011.

24. Lynch TJ, Bell DW, Sordella R, et al: Activating mutations in the epidermal growth factor receptor underlying responsiveness of non-small-cell lung cancer to gefitinib. N Eng J Med 2004, 350:2129-2139.

25. Yun CH, Boggon TJ, Li Y, et al: Structures of lung cancer-derived EGFR mutants and inhibitor complexes: mechanism of activation and insights into differential inhibitor sensitivity. Cancer Cell 2007, 11:217-227.

26. Kobayashi S, Boggon TJ, Dayaram T, et al: EGFR mutation and resistance of non-small-cell lung cancer to gefitinib. N Engl J Med 2005, 352:786-792.

27. Pao W, Miller VA, Politi KA, et al: Acquired resistance of lung adenocarcinomas to gefitinib or erlotinib is associated with a second mutation in the EGFR kinase domain. PLoS Med 2005, 2:e73.

28. Kim ES, Hirsh V, Mok T, et al: Gefitinib versus docetaxel in previously treated non-small-cell lung cancer (INTEREST): a randomised phase III trial. Lancet Oncol 2008, 372:1809-1818.

29. Ciuleanu T, Stelmakh L, Cicenas S, et al: Efficacy and safety of erlotinib versus chemotherapy in second-line treatment of patients with advanced, nonsmall-cell lung cancer with poor prognosis (TITAN): a randomized multicentre, open-label, phase 3 study. Lancet Oncol 2012, 13:300-308.

30. Cappuzzo F, Ciuleanu T, Stelmakh L, et al: Erlotinib as maintenance treatment in advanced non-small-cell lung cancer: a multicentre, randomised, placebo-controlled phase 3 study. Lancet Oncol 2010, 11:521-529.

31. Mendelsohn J, Baselga J: Epidermal growth factor receptor targeting in cancer. Semin Oncol 2006, 33:369-385.

32. Rosell R, Robinet G, Szczesna A, et al: Randomized phase II study of cetuximab plus cisplatin/ vinorelbine compared with cisplatin/ vinorelbine alone as first-line therapy in EGFR-expressing advanced nonsmall-cell lung cancer. Ann Oncol 2008, 19:362-369.

33. Pirker R, Pereira J, Szczesna A, et al: Cetuximab plus chemotherapy in patients with advanced non-small-cell lung cancer (FLEX): an open-label randomised phase III trial. Lancet Oncol 2009, 373:1525-1531.

34. Lynch TJ, Patel T, Dreisbach $L$, et al: Cetuximab and first-line taxane/ carboplatin chemotherapy in advanced non-small-cell lung cancer: results of the randomized multicenter phase III trial BMS099. J Clin Oncol 2010, 28:911-917.

35. Douillard JY, Shepherd FA, Hirsh V, et al: Molecular predictors of outcome with gefitinib and docetaxel in previously treated non-small-cell lung 
cancer: data from the randomized phase III INTEREST trial. J Clin Oncol 2010, 28:744-752.

36. Brugger $W$, Triller N, Blasinska-Morawiec $M$, et al: Prospective molecular marker analyses of EGFR and KRAS from a randomized, placebocontrolled study of erlotinib maintenance therapy in advanced nonsmall-cell lung cancer. J Clin Oncol 2011, 29:4113-4120.

37. Milella M, Nuzzo C, Bria E, et al: EGFR molecular profiling in advanced NSCLC a prospective phase II study in molecularly/clinically selected patients pretreated with chemotherapy. J Thorac Oncol 2012, 7:672-680.

38. Cadranel J, Mauguen A, Faller M, et al: Impact of systematic EGFR and KRAS mutation evaluation on progression-free survival and overall survival in patients with advanced non-small-cell lung cancer treated by erlotinib in a French prospective cohort (ERMETIC Project-Part 2). J Thorac Oncol 2012, 7:1490-1502.

39. Bai H, Mao L, Wang HS, et al: Epidermal growth factor receptor mutations in plasma DNA samples predict tumor response in Chinese patients with stages IIIB to IV non-small-cell lung cancer. J Clin Oncol 2009, 27:2653-2659

40. Bell DW, Lynch TJ, Haserlat SM, et al: Epidermal growth factor receptor mutations and gene amplification in non-small-cell lung cancer: molecular analysis of the IDEAL/INTACT gefitinib trials. J Clin Oncol 2005, 23:8081-8092

41. Eberhard DA, Johnson BE, Amler LC, et al: Mutations in the epidermal growth factor receptor and in KRAS are predictive and prognostic indicators in patients with non-small-cell lung cancer treated with chemotherapy alone and in combination with erlotinib. J Clin Oncol 2005, 23:5900-5909.

42. Fukuoka M, Wu YL, Thongprasert S, et al: Biomarker analysis and final overall survival results from a phase III, randomized, open-label, first-line study of gefitinib versus carboplatin/paclitaxel in clinically selected patients with advanced non-small-cell lung cancer in Asia (IPASS). J Clin Oncol 2011, 29:2866-2874.

43. Hirsch FR, Herbst RS, Olsen C, et al: Increased EGFR gene copy number detected by fluorescent in situ hybridization predicts outcome in nonsmall-cell lung cancer patients treated with cetuximab and chemotherapy. J Clin Oncol 2008, 26:3351-3357.

44. Khambata-Ford S, Harbison CT, Hart LL, et al: Analysis of potential predictive markers of cetuximab benefit in BMS099, a phase III study of cetuximab and first-line taxane/carboplatin in advanced non-small-cell lung cancer. J Clin Oncol 2010, 28:918-927.

45. O'Byrne KJ, Gatzemeier U, Bondarenko I, et al: Molecular biomarkers in non-small-cell lung cancer: a retrospective analysis of data from the phase 3 FLEX study. Lancet Oncol 2011, 12:795-805.

46. Begg AC, Stewart FA, Vens C: Strategies to improve radiotherapy with targeted drugs. Nat Rev Cancer 2011, 11:239-253.

47. Riesterer $O$, Milas L, Ang KK: Use of molecular biomarkers for predicting the response to radiotherapy with or without chemotherapy. J Clin Oncol 2007, 25:4075-4083.

48. Bonner JA, Harari PM, Giralt J, et al: Radiotherapy plus cetuximab for locoregionally advanced head and neck cancer: 5-year survival data from a phase 3 randomised trial, and relation between cetuximabinduced rash and survival. Lancet Oncol 2010, 11:21-28.

49. Aupérin A, Le Péchoux $C$, Rolland $E$, et al: Meta-analysis of concomitant versus sequential radiochemotherapy in locally advanced non-small-cell lung cancer. J Clin Oncol 2010, 28:2181-2190.

50. Bianco C, Tortora G, Bianco R, et al: Enhancement of antitumor activity of ionizing radiation by combined treatment with the selective epidermal growth factor receptor-tyrosine kinase inhibitor ZD1839 (Iressa). Clin Cancer Res 2002, 8:3250-3258.

51. Park SY, Kim YM, Pyo H: Gefitinib radiosensitizes non-small cell lung cancer cells through inhibition of ataxia telangiectasia mutated. Mol Cancer 2010, 9:222

52. Tanaka T, Munshi A, Brooks C, et al: Gefitinib radiosensitizes non-small cell lung cancer cells by suppressing cellular DNA repair capacity. Clin Cancer Res 2008, 14:1266-1273.

53. Wang M, Morsbach F, Sander D, et al: EGF receptor inhibition radiosensitizes NSCLC cells by inducing senescence in cells sustaining DNA double-strand breaks. Cancer Res 2011, 71:6261-6269.

54. Akashi Y, Okamoto I, Iwasa T, et al: Enhancement of the antitumor activity of ionizing radiation by nimotuzumab, a humanised monoclonal antibody to the epidermal growth factor receptor, in non-small cell lung cancer cell lines of differing epidermal growth factor receptor status. $\mathrm{Br} J$ Cancer 2008, 98:749-755.

55. Okamoto I, Takahashi T, Okamoto H, et al: Single-agent gefitinib with concurrent radiotherapy for locally advanced non-small cell lung cancer harboring mutations of the epidermal growth factor receptor. Lung Cancer 2011, 72:199-204.

56. Choong NW, Mauer AM, Haraf DJ, et al: Phase I trial of erlotinib-based multimodality therapy for inoperable stage III non-small cell lung cancer. J Thorac Oncol 2008, 3:1003-1011.

57. Rothschild S, Bucher SE, Bernier J, et al: Gefitinib in combination with irradiation with or without cisplatin in patients with inoperable stage III non-small cell lung cancer: a phase I trial. Int J Radiat Oncol Biol Phys 2011, 80:126-132.

58. Wang J, Xia TY, Wang YJ, et al: Prospective study of epidermal growth factor receptor tyrosine kinase inhibitors concurrent with individualized radiotherapy for patients with locally advanced or metastatic non-smallcell lung cancer. Int J Radiat Oncol Biol Phys 2011, 81:e59-e65.

59. Center B, Petty WJ, Ayala D, et al: A phase I study of gefitinib with concurrent dose-escalated weekly docetaxel and conformal threedimensional thoracic radiation followed by consolidative docetaxel and maintenance gefitinib for patients with stage III non-small cell lung cancer. J Thorac Oncol 2010, 5:69-74.

60. Stinchcombe TE, Morris DE, Lee CB, et al: Induction chemotherapy with carboplatin, irinotecan, and paclitaxel followed by high dose threedimension conformal thoracic radiotherapy (74 Gy) with concurrent carboplatin, paclitaxel, and gefitinib in unresectable stage IIIA and stage IIIB non-small cell lung cancer. J Thorac Oncol 2008, 3:250-257.

61. Ready N, Jänne PA, Bogart J, et al: Chemoradiotherapy and gefitinib in stage III non-small cell lung cancer with epidermal growth factor receptor and KRAS mutation analysis Cancer and Leukemia Group B (CALEB) 30106, a CALGB-stratified phase II trial. J Thorac Oncol 2010, 5:1382-1390.

62. Chang CC, Chi KH, Kao SJ, et al: Upfront gefitinib/erlotinib treatment followed by concomitant radiotherapy for advanced lung cancer: a moninstitutional experience. Lung Cancer 2011, 73:189-194.

63. Komaki RU, Kim YB, Wistuba II, et al: Vimentin (EMT marker protein) score predicts resistance to erlotinib and radiotherapy for patients with stage III non-small cell lung cancer on a prospective phase II trial. J Thorac Oncol 2012, 7:S220

64. Curran WJ Jr, Paulus R, Langer C: Sequential vs concurrent chemoradiation for stage III non-small cell lung cancer: randomized phase III trial RTOG9410. JNCI 2011, 22:2499.

65. Hanna N, Neubauer M, Yiannoutsos C, et al: Phase III study of cisplatin, etoposide, and concurrent chest radiation with or without consolidation docetaxel in patients with inoperable stage III non-small-cell lung cancer: the Hoosier Oncology Group and U.S. Oncology. J Clin Oncol 2008, 26:5755-5760.

66. Hughes S, Liong J, Miah A, et al: A brief report on the safety study of induction chemotherapy followed by synchronous radiotherapy and cetuximab in stage III non-small cell lung cancer (NSCLC): SCRTACH study. J Thorac Oncol 2008, 3:648-651.

67. Choi HJ, Sohn JH, Lee CG, et al: A phase I study of nimotuzumab in combination with radiotherapy in stages IIB-IV non-small cell lung cancer unsuitable for radical therapy: Korean results. Lung Cancer 2011, 71:55-59.

68. Bebb G, Smith C, Rorke S, et al: Phase I clinical trial of the anti-EGFR monoclonal antibody nimotuzumab with concurrent external thoracic radiotherapy in Canadian patients diagnosed with stage IIB, III or IV nonsmall cell lung cancer unsuitable for radical therapy. Cancer Chemother Pharmacol 2011, 67:837-845.

69. Govindan R, Bogart J, Stinchcombe T, et al: Randomized phase II study of pemetrexed, carboplatin, and thoracic radiation with or without cetuximab in patients with locally advanced unresectable non-small-cell lung cancer: Cancer and Leukemia Group B Trial 30407. J Clin Oncol 2011, 29:3120-3125.

70. Jensen $A D$, Münter MW, Bischoff $H G$, et al: Combined treatment of nonsmall cell lung cancer NSCLC stage III with intensity-modulated RT radiotherapy and cetuximab: the NEAR trial. Cancer 2011, 117:2988-2994.

71. Hallqvist $A$, Wagenius $G$, Rylander $H$, et al: Concurrent cetuximab and radiotherapy after docetaxel-cisplatin induction chemotherapy in stage III NSCLC: Satellite-A phase II study from the Swedish Lung Cancer Study Group. Lung Cancer 2011, 71:166-172. 
72. Blumenschein GR Jr, Paulus R, Curran WJ, et al: Phase II study of cetuximab in combination with chemoradiation in patients with stage IIIA/B nonsmall-cell lung cancer: RTOG 0324. J Clin Oncol 2011, 29:2312-2318.

73. Hammerman PS, Pänne PA, Johnson BE: Resistance to epidermal growth factor receptor tyrosine kinase inhibitors in non-small cell lung cancer. Clin Cancer Res 2009, 15:7502-7509.

74. Engelman JA, Zejnullahu K, Mitsudomi T, et al: MET amplification leads to gefitinib resistance in lung cancer by activating ERBB3 signaling. Science 2007, 316:1039-1042.

75. Yun $\mathrm{CH}$, Mengwasser KE, Toms AV, et al: The T790M mutation in EGFR kinase causes drug resistance by increasing the affinity for ATP. Proc Natl Acad Sci USA 2008, 105:2070-2075.

76. Su KY, Chen HY, Li KC, et al: Pretreatment epidermal growth factor receptor (EGFR) T790M mutation predicts shorter EGFR tyrosine kinase inhibitor response duration in patients with non-small-cell lung cancer. J Clin Oncol 2012, 30:433-440.

77. Miller VA, Hirsh V, Cadranel J, et al: Afatinib versus placebo for patients with advanced, metastatic non-small-cell lung cancer after failure of erlotinib, gefitinib, or both, and one or two lines of chemotherapy (LUXLung 1): a phase 2b/3 randomised trial. Lancet Oncol 2012, 13:528-538.

78. Yang J CH, Schuler MH, Yamamoto N, et al: LUX-Lung 3: a randomized, open-label, phase III study of afatinib versus pemetrexed and cisplatin as first-line treatment for patients with advanced adenocarcinoma of the lung harboring EGFR-activating mutations. Abstract, ASCO 2012.

79. Nakagawa T, Takeuchi S, Yamada T, et al: Combined therapy with mutantselective EGFR inhibitor and Met kinase inhibitor for overcoming erlotinib resistance in EGFR-mutant lung cancer. Mol Cancer Ther 2012, 11:2149-2157.

80. Ohashi K, Sequist LV, Arcila ME, et al: Lung cancers with acquired resistance to EGFR inhibitors occasionally harbor BRAF gene mutations but lack mutations in KRAS, NRAS, or MEK1. Proc Natl Acad Sci USA 2012, 109:E2127-E2133.

81. Yamamoto C, Basaki Y, Kawahara A, et al: Loss of PTEN expression by blocking nuclear translocation of EGR1 in gefitinib-resistant lung cancer cells harboring epidermal growth factor receptor-activating mutations. Cancer Res 2010, 70:8715-8725.

82. Roberts PJ, Stinchcombe TE, Der CJ, et al: Personalized medicine in nonsmall-cell lung cancer: is KRAS a useful marker in selecting patients for epidermal growth factor receptor-targeted therapy? J Clin Oncol 2010, 28:4769-4777

83. Linardou H, Dahabreh IJ, Kanaloupiti D, et al: Assessment of somatic k-RAS mutations as a mechanism associated with resistance to EGFR-targeted agents: a systematic review and meta-analysis of studies in advanced non-smll-cell lung cancer and metastatic colorectal cancer. Lancet Oncol 2008, 9:962-972.

84. Huang S, Armstrong EA, Benavente $S$, et al: Dual-agent molecular targeting of the epidermal growth factor receptor (EGFR): combining anti-EGFR antibody with tyrosine kinase inhibitor. Cancer Res 2004, 64:5355-5362.

85. Choi EJ, Ryu YK, Kim SY, et al: Targeting epidermal growth factor receptorassociated signaling pathways in non-small cell lung cancer cells: implications in radiation response. Mol Cancer Res 2010, 8:1027-1036.

86. Nagata $Y$, Takahashi A, Ohnishi K, et al: Effect of rapamycin, an mTOR inhibitor, on radiation sensitivity of lung cancer cells having different p53 gene status. Int J Oncol 2010, 37:1001-1010.

\section{Submit your next manuscript to BioMed Central and take full advantage of:}

- Convenient online submission

- Thorough peer review

- No space constraints or color figure charges

- Immediate publication on acceptance

- Inclusion in PubMed, CAS, Scopus and Google Scholar

- Research which is freely available for redistribution

Submit your manuscript at www.biomedcentral.com/submit 